\title{
Morphological, Molecular and Pollen Grain Investigations of Salix Species in Egypt
}

\author{
Walaa A. Hassan ${ }^{1 *}$ \\ Rahma Alshamrani ${ }^{2}$ \\ Emad Alsherif ${ }^{4}$
}

Wafaa M. Amer ${ }^{3}$

Received 7/5/2020, Accepted 8/11/2020, Published Online First 6/12/2020, Published 1/3/2021

This work is licensed under a Creative Commons Attribution 4.0 International License.

\begin{abstract}
${ }^{1}$ Department of Biology, College of Science, Princess Nourah Bint Abdulrahman University, Riyadh, Saudi Arabia, Botany \& Microbiology Department, Faculty of Science, Beni-Suef University, Egypt

${ }^{2}$ Biological Sciences Department, King Abdulaziz University, Jeddah.

${ }^{3}$ Botany \& Microbiology Department, Faculty of Science, Cairo University, Egypt

${ }^{4}$ Biology Department, Faculty of Science and Arts, Jeddah University, Saudi Arabia، Botany \& Microbiology Department, Faculty of Science, Beni-Suef University, Egypt

* Corresponding author: azmeyw@gmail.com*, rahmais@ hotmail.com, wamer@sci.cu.edu.eg, emad702001@yahoo.com

*ORCID ID: https://orcid.org/0000-0001-7605-9058*, https://orcid.org/0000-00o2-247-5081, https://orcid.org/00000003-0126-6719 , https://orcid.org/0000-0002-7614-9595
\end{abstract}

\begin{abstract}
:
Genus Salix is among family Salicaceae, distributing in the northern hemisphere. It is represented in Egypt by two species (Salix mucronata and Salix tetrasperma). The classification of Salix at the generic and infra-generic levels is still outstanding. We have agreed to list the Egyptian species of this genus. We collected them during field trips to most Egyptian habitats; fresh and herbarium specimens were subjected to taxonomic revision based on morphological characters; scanning electron microscope (SEM) for pollen grains; isozyme analysis using esterase and peroxidase enzymes and genetic diversity using random amplified polymorphic DNA (RAPD). We recorded that both sexes of $S$. mucronata existed but there were only male trees from $S$. tetrasperma. SEM of pollen grain revealed that there were many differences between them. Also, the application of isozyme analysis giving 12 sex indicating bands. In addition, ten RAPD primers retrieved a total of 227 amplified bands ( 77 for female $S$. mucronata, 74 for male $S$. mucronata and 76 for male $S$. tetrasperma).
\end{abstract}

Key words: Egypt, Isozyme, Pollen grain, RAPD, Salix.

\section{Introduction:}

Genus Salix Linnaeus (1753: 1015) of Salicaceae, is known as willows commonly (1). It is moisture loving trees and shrubs, with long lanceolated leaves, it is planted around banks to hold soil in suburban yards (2). It comprises ca. 350-520 species, distributed mainly in the northern hemisphere, absent in Oceania, except the introduced species (3). The systematics taxonomy and of Salix have proven extremely difficult because of their simple flowers, dioecious reproduction, common natural hybridization, and large intraspecific phenotypic variation (1). On the other hand, (2) revealed that the classification of Salix at the generic and infrageneric levels is still unresolved; also, the essential taxonomic difficulties of the genus Salix are too increased by their high phenotypic plasticity and great variation in diagnostic morphological characters

In Egypt it is represented by two species; Salix tetrasperma Roxb., Salix safsaf Trautv. (Latter treated as Salix mucronata Thunb.). It is distributed in Nile and Faiyum regions, in addition to Mediterranean coastal strip and eastern desert, also, both species are represented in western desert Oases (4).

In plant taxonomy, the best evidence in the flowering plants, especially in the angiosperms is the application of pollen morphology (5). Also (6) mentioned that pollen morphological characters were useful in the investigation of the Asteraceae family, as well as that of some of its genera and species. Pollen grain in angiosperm is clearly divisible into two different types: heteropolar, 
bilateral, boat-shaped monosulcate pollen versus isopolar, radio-symmetric, globose tricolpate pollen (7). Wodehouse RP 1937 (8) revealed that the pollen grain of Salix is tricolpate and heavily reticulate, on the other hand (9) cited that the pollen grain of Salix usually 3-colporoidate (sometimes 2-colporoidate),subprolate or more frequently prolate.

Random Amplification Polymorphic DNA (RAPD) is a PCR-based technique introduced by (10). RAPD markers technique can be used in conservation genetics, population genetics, genetic diversity among crop species, and in taxonomical classification studies (11). Markers relationships provided a quick genetic marker for the study of species in addition (12) revealed that the use of these markers is a cost-effective, fast, highly discriminative and reliable technique. RAPD marker has been used for determining sex in Salix viminalis, Pistacia vera, Atriplex garrettii and Trichosanthes dioica (13). The inter- and interaspecific relationships within Salix species in Egypt can be studied using RAPD markers.

The isozyme is the basic analytical tool to study the molecular mechanism. Also, (2) revealed that isozymes and allozymes are among the biochemical markers with a paramount importance where they have been the most important type of genetic marker used for many different applications in many species. As an important genetic marker, it could be used to detect the inheritance and variance among different species or different cultivars at the molecular level. It also could be as a biochemical marker to study the tolerance of plant to stress (14).

Till now the classification of Salix at the generic and infrageneric levels is still unresolved (2). Because molecular markers have so many advantages over morphological markers, we decided to classify the Egyptian species of this genus using RAPD and isozymes markers in addition to pollen grain characters.

\section{Material and Methods:}

We collected 30 samples (11 male $S$. tetrasperma, one male $S$. mucronata and 18 female $S$. mucronata) from various localities across the country during spring 2007 and 2008 (Fig. 1), and specimens were checked at Egyptian herbaria. The lists of species recorded were identified according to (15),(16), (4).

The fresh and herbarium specimens were subjected to taxonomic revision based on macroand micro-morphological characters. The macromorphological description is mainly based on field and laboratory studies with reference to (4).

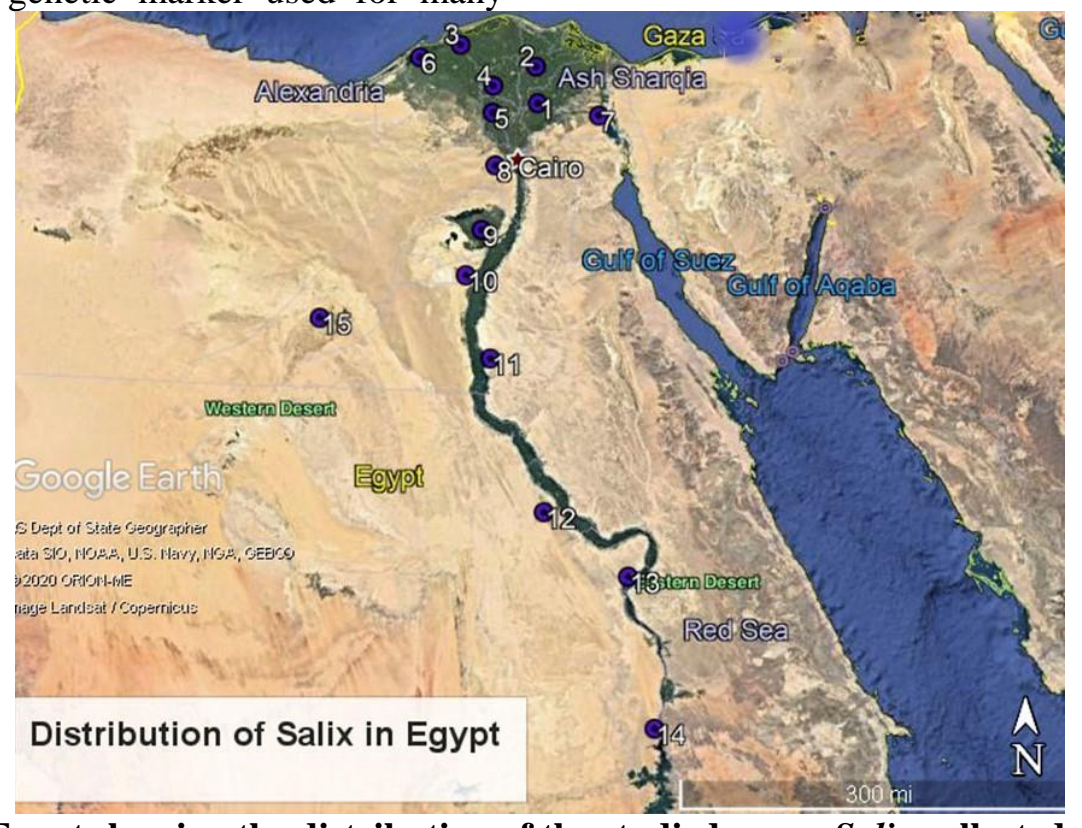

Figure 1. Map of Egypt showing the distribution of the studied genus Salix collected during this study. 


\section{Laboratory analysis}

Macro-morphological characters cited in this work are based on the earlier works of (16),(4) and the current specimens descriptions.

Micro-morphological characters including pollen grains investigation, isozyme and RAPD analysis have been carried out as follows:

\section{Pollen grain}

Pollen grains of the Salix species under investigation were obtained from the collected samples. Materials were prepared for SEM by mounting acetolyzed pollen grain on clean stubs using double sided cello tape, coated with gold and examined by a JOEL JSM 5400 LV scanning electron microscope operated at accelerated voltage of $15 \mathrm{kv}$, at Electron Microscope Unite, Assiut University. The description of pollen grains has been demonstrated with the literatures as (17)

\section{Isozymes}

Juvenile leaves of Salix species under investigation have been collected during March from the field. Leaves have been kept in $-20^{\circ} \mathrm{C}$ for isozyme studying.

Esterase and peroxidase (PRX) have been assayed using $100 \mathrm{mg}$ freshly harvested leaves of the studied species according to the method of (14).

\section{DNA isolation}

DNA samples have been extracted from 50 $\mathrm{mg}$ of juvenile leaf tissues in each sample; according to (18). Sequences of the used primers are outlined in Table 1.

Table 1. Primers used for RAPD analysis

\begin{tabular}{ll}
\hline Primer code & Sequence $\left(\mathbf{5}^{\prime}\right.$ - $\mathbf{3}^{\prime}$ ) \\
\hline OPA-05 & AGGGGTCTTG \\
OPA-07 & GAAACGGGTG \\
OPA-18 & AGGTGACCGT \\
OPA-20 & GTTGCGATCC \\
OPD-01 & ACCGCGAAGG \\
OPD-04 & TCTGGTGAGG \\
OPO-02 & ACG TAG CGT C \\
OPO-14 & AGC ATG GCT C \\
OPP-01 & CCTCTGCCCA \\
OPP-16 & CCAAGCTGCC \\
\hline
\end{tabular}

\section{Results:}

\section{Taxonomic results}

Specimens' examination (fresh and herbarium) revealed that genus Salix in Egypt is represented by two wild species ( $S$. mucronata and $S$. tetrasperma). This work clarifies that female $S$. mucronata Thunb trees are distributed along Nile valley and delta and extends eastward to Ismailia in the eastern desert, while the few male $S$. mucronata Thunb trees were traced only in Fayium region. On the other hand, S. tetrasperma Roxb has been traced only as male trees but female trees are never found in Egypt. This species is distributed in Nile delta and northern part of the Nile valley, to $28^{\circ} \mathrm{N}$, and not traced in the southern part.

\section{Morphological features}

Salix mucronata Thunb., Prodr. P1. Cap. 6(1794).

The plant is shrub or tree up to $8 \mathrm{~m}$, deciduous, bark brownish. Leaves $12 \times 2 \mathrm{~cm}$ (female plant) $16.3 \times 3.2 \mathrm{~cm}$ (male plant), lanceolate, serrate, acute, pale lower surface. Juvenile leaves covered with simple hairs. Petiole $0.8-1.5 \mathrm{~cm}$ in female plant, $0.3-2.1 \mathrm{~cm}$ in male one. Stipules persistent, ovate, serrulate, acute. Female inflorescence catkin $1.5-3.1 \times 0.3-0.7 \mathrm{~cm}$, yellow to dark brown, peduncle to $0.4 \mathrm{~cm}$. Bract elliptic, entire, acuminate. Flower $2.0-2.5 \mathrm{~mm}$, yellow. Bract sagitate, entire, acute, hairy of simple hairs. Ovary $0.1-0.9 \times 0.4-0.6 \mathrm{~mm}$, yellow, glabrous. Style 0.2 - $0.4 \mathrm{~mm}$, brown. Stigma 0.1$0.3 \mathrm{~mm}$, brown. Capsule 5.0 - $6.0 \mathrm{~mm}$, ovoid. Male inflorescence catkin $3.9-4.5 \times 0.8-1.0 \mathrm{~cm}$, whitish yellow. Peduncle $0.3-0.5 \mathrm{~cm}$. Bract lanceolate, serrulate, acute. Floral bract $6.0-7.0$ × $3.0-3.5 \mathrm{~cm}$, ovate, entire, acute, covered by simple hairs. Stamen $6-8$, anther $1.0-1.3 \mathrm{~mm}$, filament hairy lower half as shown in Fig. 2.

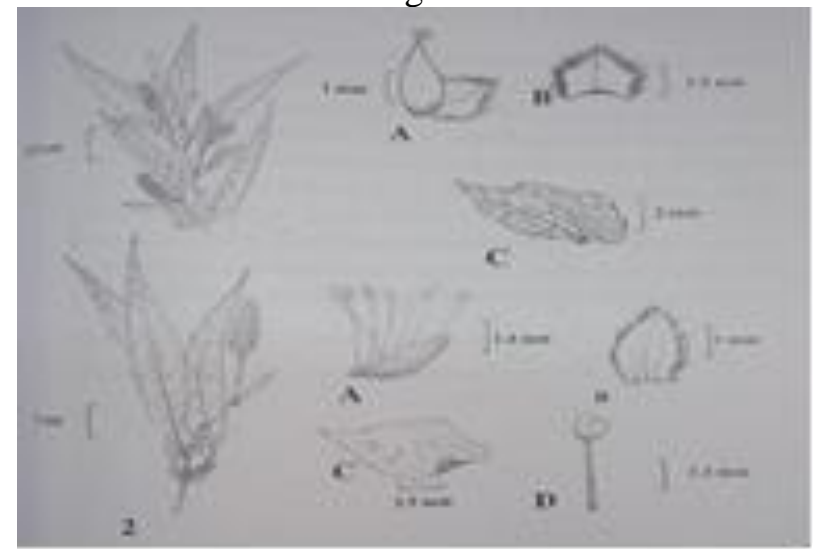

Figure 2. Salix mucronata; 1 and 2 branches with mature leaves and inflorescence to female and male plant; respectively. A, female and male flowers; B, floral bract; C, stipule; D(2), stamen.

\section{Salix tetrasperma Roxb., P1. Coast Corom. 1:66, t.97 (1798)}

Shrub or tree is up to $12 \mathrm{~m}$, deciduous, and it is sometimes evergreen, dark brown. Leaves to 18 x $6 \mathrm{~cm}$, in Egypt leaves 18(-25) x 6(-7.7) cm, broadly ovate-lanceolate, serrate, acuminate, pale lower surface, juvenile leaves are covered with simple hairs. Petiole $0.4-1.6 \mathrm{~cm}$. Stipules persistent, ovate, serrulate, acute. Male inflorescence catkin, in Egypt it measures (2.5 -) 8 $(-11)$ x $0.5-1.0 \mathrm{~cm}$, pale yellow. Peduncle to $0.7 \mathrm{~cm}$. 
Bract lanceolate, entire, acuminate. Flower 2.0- $2.6 \mathrm{~mm}$, yellow. Perianth $1.1-1.2 \mathrm{~mm}$ long, $0.2-$ $0.3 \mathrm{~mm}$ wide, entire, acute, covered with simple unicellular hairs. Stamens 6, anther $1.0 \times 1.3 \mathrm{~mm}$, filament hairy lower half. Female flower in catkin 8 $-12 \mathrm{~cm}$; ovary sessile, hairy; fruit pyriform; female trees less common in Egypt than male trees as shown in Fig. 3.

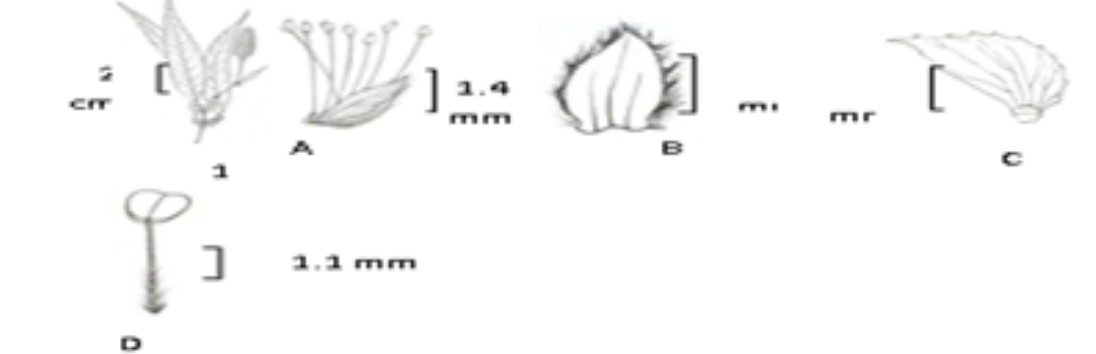

Figure 3. Salix tetrasperma; 1, branch with mature leaves and inflorescence; A, flower; B, floral bract; C, stipule; D, stamen (female plant not traced in Egypt).

\section{Key to the Salix species}

leaves more than $6.0 \mathrm{~cm}$ diameter; inflorescence up to $11.0 \mathrm{~cm}$ long. .................male $S$. tetrasperma

leaves not exceeding $3.5 \mathrm{~cm}$ diameter; inflorescence not exceeding $4.5 \mathrm{~cm}$ long $\ldots \ldots \ldots . .$. male $S$. mucronata

leaves not exceeding $2 \mathrm{~cm}$ diameter; inflorescence not exceeding $3.1 \mathrm{~cm}$ long female $S$. mucronata

\section{Pollen grains of Salix spp.:}

The result of pollen grains investigations as seen by SEM are outlined in Table 2. The pollen grain shape of the studied Salix species is radiosymmetric, elliptical and tricolpate (Fig. 4C and $\mathrm{D}$ ). The pollen grain size is outlined in Table 2, denoting that the largest pollen grain is that of $S$. tetrasperma (E x P: $13.33 \times 15.50 \mu \mathrm{m})$. While the smallest pollen grain is of $S$. mucronata (E x P: $11.51 \times 19.31 \mu \mathrm{m})$.

The data, outlined in Table 2, demonstrate that the colpus length of the studied Salix species can be used as differential character between them. The colpus length in $S$. mucronata not exceeding 10 $\mu \mathrm{m}$ (Table 2, Fig. 4B). While the colpus length of $S$. tetrasperma (Fig. 4E) is nearly equal (up to 16.50 $\mu \mathrm{m}$; Table 2).

Pollen of the studied Salix species shows a dimorphism character, this means that the presence of two types of each lumen width in pollen grain. The reticulum dimorphism of the studied species appears clearly $S$. tetrasperma where it is gradually reduced towards colpei while in $S$. mucronata the lumen width has the same size all over the pollen grain (Fig. 4B and E).

The network lumen of the studied Salix species shows clearly distinguishable pattern. This pattern can be summarized as follows: the network lumen in case of $S$. tetrasperma exceeds $1.0 \mu \mathrm{m}$, while this is not applicable to $S$. mucronata. $S$. tetrasperma possesses the widest network lumen $(1.15 \times 0.85 \mu \mathrm{m}$; Fig. 4F), while that of $S$. mucronata is the smallest lumen $(0.55 \times 0.30 \mu \mathrm{m}$; Fig. 4C).

The exine sculpture of the lumen in $S$. tetrasperma appears granulate (Fig. 5F), while in $S$. mucronata is a psilolumena (Fig. 4C).

Muri of the studied species is irregular and undulate form its thickness do not exceed $1.0 \mu \mathrm{m}$, in the two species studied (Table 2, Fig. 4C and F).

Table 2. morphometric characteristics of the $S$. mucronate and $S$. tetrasperma.

\begin{tabular}{|c|c|c|c|c|c|c|}
\hline $\begin{array}{c}\text { Salix } \\
\text { species }\end{array}$ & $\mathrm{E}(\mu \mathrm{m})$ & $\mathrm{P}(\mu \mathrm{m})$ & $\mathrm{E} / \mathrm{P}$ & $\begin{array}{c}\text { Colpus } \\
\mathrm{LxW}(\mu \mathrm{m})\end{array}$ & $\begin{array}{c}\text { Lumen } \\
\mathrm{LxW}(\mu \mathrm{m})\end{array}$ & Muri $(\mu \mathrm{m})$ \\
\hline mисronata & $10.80-12.22$ & $17.50-21.11$ & 0.09 & $\begin{array}{c}7.69-11.78 \times 0.35- \\
0.76\end{array}$ & $\begin{array}{c}0.20-0.90 \times 0.10- \\
0.50\end{array}$ & $0.14-0.60$ \\
\hline tetrasperma & $\begin{array}{c}(11.51) \\
12.00-14.66\end{array}$ & $\begin{array}{c}(19.31) \\
15.00-16.00\end{array}$ & 0.03 & $\begin{array}{c}(9.73 \times 0.55) \\
13.30-17.00 \times 0.60 \\
-1.50\end{array}$ & $\begin{array}{c}(0.55 \times 0.30) \\
0.20-2.10 \times 0.20- \\
1.50\end{array}$ & $\begin{array}{c}(0.37) \\
0.27-0.90\end{array}$ \\
\hline & (13.33) & $(15.50)$ & & $(15.15 \times 1.05)$ & $(1.15 \times 0.85)$ & $(0.58)$ \\
\hline
\end{tabular}

E: equatorial diameter

P: polar axis

Mean value between brackets. 

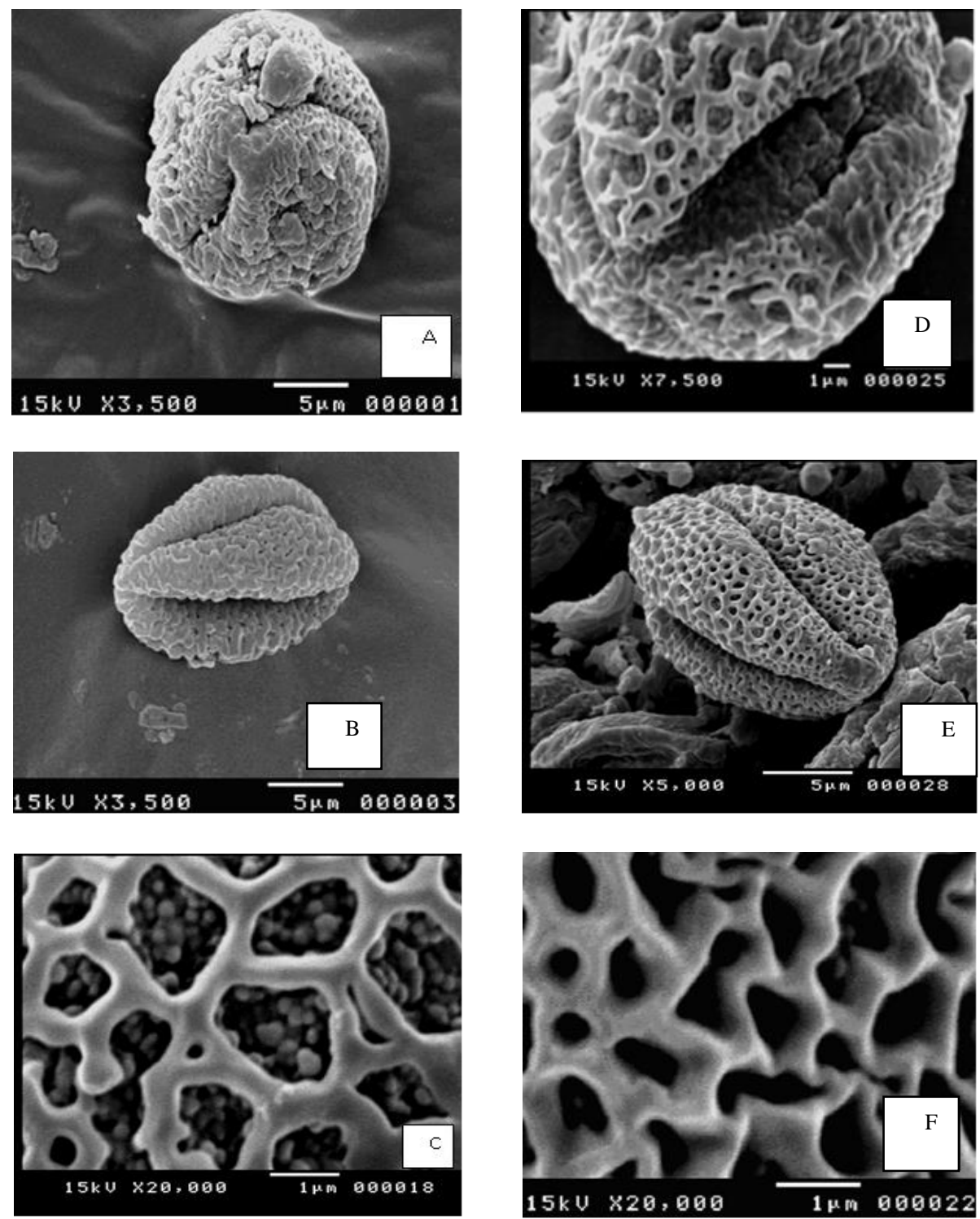

Figure 4. SEM micrograph of pollen grain of the studied species $S$. mucronata and $S$. tetrasperma, A \& D. polar view, B \& E. equatorial view, C \& F. exine sculpture.

\section{Isozyme analysis:}

The zymogrames for Esterase and Peroxidase are outlined in Fig. 5A and B.

Esterase: Nine esterase bands were developed in the studied Salix species: namely $\alpha, \beta$ and $\alpha / \beta$ esterase. Where $\beta 3$ is a common esterase band in the studied male and female of $S$. mucronata specimens. $\alpha 4$ esterase band developed only in male of $S$. tetrasperma specimens. $\beta 2$ band present in all the Salix specimens studied, in all localities and it appeared as a sex non -related isozyme (Table 3, Fig. 5A).

Peroxidase (PRX): The developed PRX zymograme showed three bands. The band 3 at $\mathrm{Rf}=$ 0.85 appeared only in female $S$. mucronata. On the other hand, the band 1 at $\mathrm{Rf}=0.27$ presents in all studied specimens (Table 3, Fig. 5B). 
Table 3. The Pattern of Esterase and Peroxidase isozymes in S. mucronate and S. tetrasperma.

\begin{tabular}{|c|c|c|c|c|c|c|c|c|c|}
\hline \multirow{2}{*}{$\begin{array}{l}\text { Taxa } \\
\text { Sample no. }\end{array}$} & \multirow[t]{2}{*}{$\mathbf{R F}$} & \multicolumn{3}{|c|}{ S. tetrasperma } & \multicolumn{5}{|c|}{ S. mucronata } \\
\hline & & 1 & 2 & 3 & 4 & 5 & 6 & 7 & 8 \\
\hline Isozyme & & $\hat{0}$ & $\hat{\sigma}$ & $\hat{0}$ & $\hat{o}$ & 우 & q & q & 우 \\
\hline \multicolumn{10}{|l|}{ Esterase } \\
\hline$\alpha 1$ & 0.06 & ++ & + & - & +++ & + & +++ & + & ++ \\
\hline$\alpha 2$ & 0.2 & + & - & - & ++ & - & +++ & + & ++ \\
\hline$\alpha 3$ & 0.23 & + & + & + & - & + & - & - & - \\
\hline$\alpha 4$ & 0.25 & ++ & +++ & + & - & - & - & - & - \\
\hline$\alpha 5$ & 0.3 & - & - & - & +++ & - & +++ & + & + \\
\hline $\boldsymbol{\alpha} / \boldsymbol{\beta}$ & 0.43 & - & ++ & + & - & - & - & - & - \\
\hline$\beta 1$ & 0.49 & - & +++ & ++ & - & - & - & - & - \\
\hline$\beta 2$ & 0.56 & ++ & +++ & +++ & +++ & +++ & +++ & ++ & +++ \\
\hline$\beta 3$ & 0.72 & - & - & - & ++ & + & ++ & ++ & ++ \\
\hline \multicolumn{10}{|l|}{ Peroxidase } \\
\hline Band 1 & 0.27 & + & + & + & + & + & + & + & + \\
\hline Band 2 & 0.77 & ++ & ++ & +++ & +++ & - & - & +++ & +++ \\
\hline Band 3 & 0.85 & - & - & - & - & ++ & ++ & - & - \\
\hline
\end{tabular}

$(-)$ : absence of band.

$(+)$ : presence of band (increasing in number of + sign means increasing in strength of band).

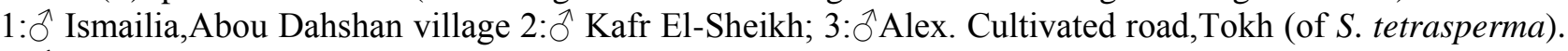
4: $\widehat{~}$ Beni-Suef-El Fayium road, $22 \mathrm{Km}$ east El Faiyoum; 5: 9 Beni-suef-El Fayium road, $14 \mathrm{Km}$ west BeniSuef; 6: Draw-Aswn road, $10 \mathrm{Km}$ south Draw; 7:우 Beni-Suef-El Fayium road, 12Km west Beni-Suef; 8: $ᄋ$ Beni-Suef-Cairo road, $50 \mathrm{Km}$ south Giza (of $S$. mucronata).
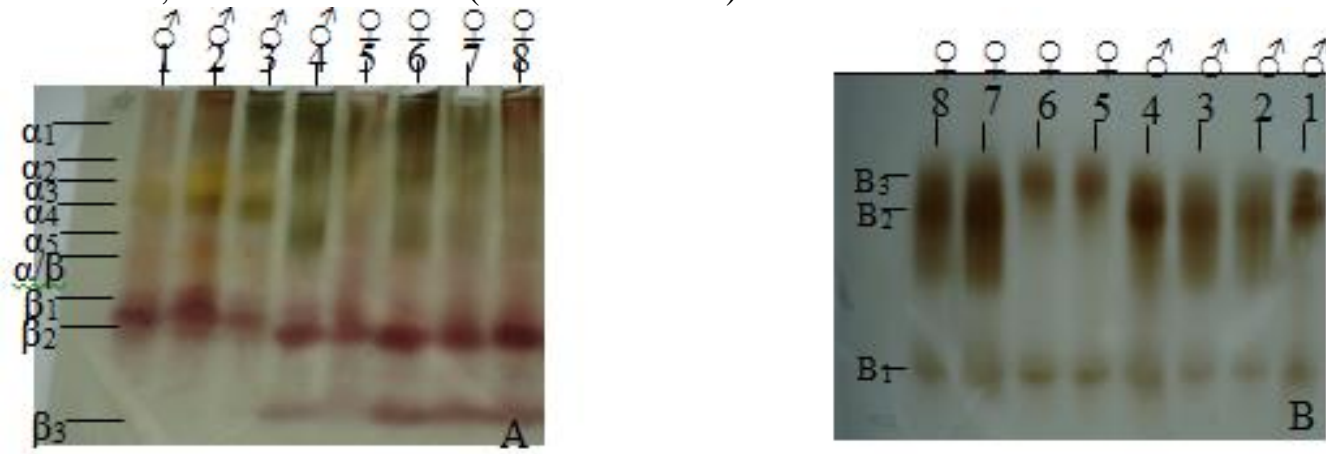

Figure 5. Zymograms of the studied Salix specimens: A: Esterase and B: Peroxidase. Specimens 1-3: $S$. tetrasperma and 4-8: S. mucronata.

\section{RAPD analysis:}

RAPD results outlined in Fig.6 A,B and C displayed three examples of the polymorphism between Salix species using ten positive primers ( OPP-16, OPD-01, OPP-01, OPA-07, OPA-20, OPO-14, OPA-05, OPA-18, OPD-04 and opo-02; Table 4).

The number of scorable bands per primer varied between 8 as in primers OPD-04 \& OPO-02, (Fig. 6B) and 16 as in primer OPO-14, (Fig. 6C), giving a total of 227 bands. Out of these bands, there are 37 bands showed unimorphism in both Salix species and presence of 23 bands characterized $S$. tetrasperma from $S$. mucronata
(Table 4, Fig. 6 A, B and C). Out of the ten screened RAPD primers, only eight primers (OPD01, OPP-01, OPA-07, OPA-20, OPO-14, OPA-05, OPA-18 and OPD-04) showed polymorphism between male and female Salix. OPD-01 produced $1300 \mathrm{bp}$ band, and OPA-05 produced 830bp, 800bp and $620 \mathrm{bp}$ bands in male $S$. mucronata only. On the other hand, female $S$. mucronata showed a large number of the developed bands in seven primers among these bands are: bands at $900 \mathrm{bp}$ and $870 \mathrm{bp}$ developed by OPP-01 primer and bands at 800,700 and $650 \mathrm{bp}$ developed by OPA-07.

On the other hand, number of bands is differentiated between male $S$. mucronata and $S$. 
tetrasperma. like 2000bp and 650bp bands amplified by the OPP-16, 600bp and 550bp bands appeared in OPD-01, 2000bp also, 800bp, 700bp, $570 \mathrm{bp}$ and $520 \mathrm{bp}$ bands amplified by the OPO-02 primer from the genomic DNA of all the male $S$. tetrasperma entries was absent in the PCR products of the DNAs from all the male $S$. mucronata entries.
In addition, there were six primers (OPA 07, OPA - 20, OPO-14, OPA - 05, OPA- 18 and OPD- 04) that give bands difference between male (S. mucronata and $S$. tetrasperma) and female ( $S$. mucronata) as shown in Table 4.

Table 4. Ten RAPD primers and their respective bands in (S. mucronata and S. tetrasperma)

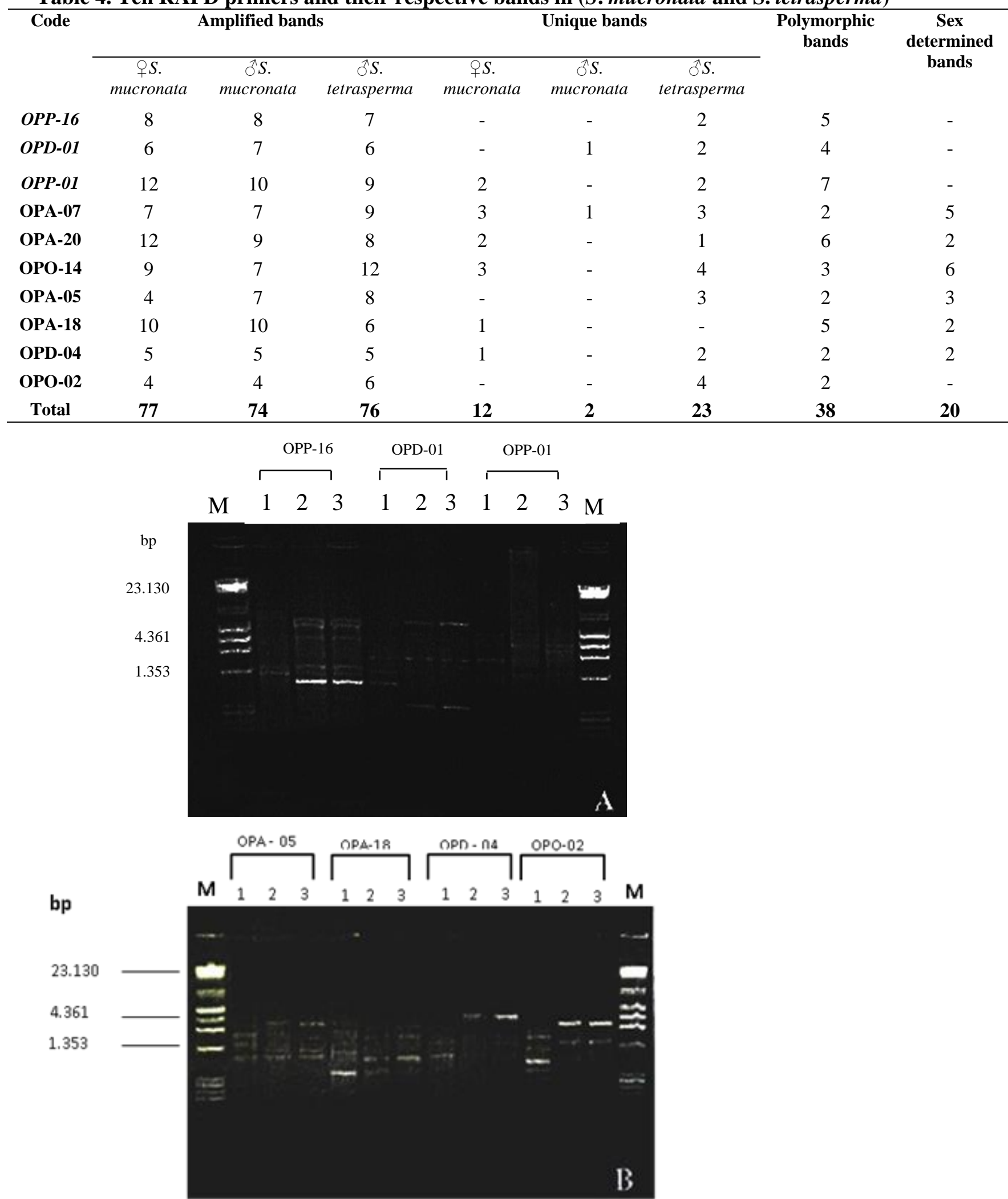




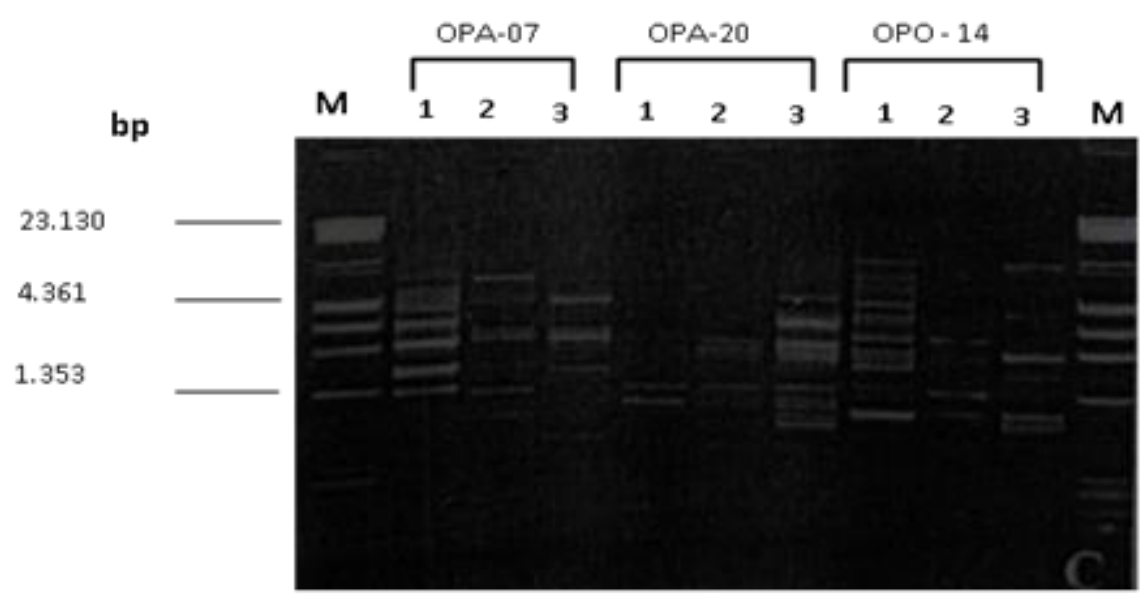

Figure 6. A, B and C: RABD pattern of the Salix species studied using ten primers: 1 त S. tetrasperma; $2 \uparrow$ S. mucronata; 3 S. mucronata

\section{Discussion:}

Genus Salix in Egypt is represented by two wild species ( $S$. mucronata and S. tetrasperma). This result is supported by earlier studies of $(4,16)$. Leaves of $S$. mucronate is narrower than that of $S$. tetrasperma which is supported by $(4,17)$.

The esterase and peroxidase patterns showed variability in the anodal region among all tested specimens. The appearance of these bands may be due to 1 . The presence of several genes controls these isozymes. 2. Their allelic states (homozygous or heterozygous). 3. Quaternary structure of the protein products; and 4. Their subcellular compartmentalization (19).

The developed zympgrams showed the presence of characteristic bands ( $\beta 2$ in esterase, Band 1 in peroxidase) to Salix species. Esterase and peroxidase revealed the presence of sex differential bands among them: $\alpha 2, \alpha 3$ and $\alpha 5$ esterase and Band $2 \&$ Band 3 in case of peroxidase. These bands appeared to be sex - linked bands. On the other hand, there are other sex bands that are not deferential among them $\alpha 1, \beta 2$ and $\beta 3$ esterases and Band 1 peroxidase. Based on earlier data, esterase and peroxidase enzymes can be used for sex identification such as (20) where he claimed that in many plant species, the aspect of PRX has been used to distinguish males and females in dioecious plants, also (21) proposed that peroxidases could be exploited as a marker for sex identification in high diversity in date palm inflorescence..

The SEM investigations, carried out on the Egyptian Salix species, revealed a tricolpate, reticulate elliptical grain. This is supported by (8) who claimed that the Pollen grains of Salix are tricolpate and heavily reticulate.
The results of the present study showed that the two studied Salix species can be distinguished from each other by several characters. $S$. tetrasperma has the largest pollen grain and widest exine lumen with granulate lumen sculpture. While $S$. mucronata has the shortest colpus, smallest lumen and psilolumina lumen sculpture. This is supported by (22) where they reported that the width of lumina and muri was considered as one of the characters by which Malcolmia, Strigosella and Zuvanda species could be distinguished.

The studied Salix species possess primitive characters, such as reticulate exine. This postulation is supported by earlier study like, (23), where he proposed that family Salicaceae is a primitive dicotyledons, and occupy a very lowly position in Engler system. Also, tricolpate is another primitive feature of the studied Salix pollen grain which was confirmed by (24), they also claimed that monosulcate and tricolpate, basic types of aperture in angiosperm are represented as ancestral forms to the most advanced types.

Despite these primitive characters, the Salix pollen studied shows some advanced characters. This was established earlier by (25), who mentioned that morphology of genus Salix has some primitive characters and other advanced ones. Among the observed advanced characters are: radiosymetry of the pollen studied. This denoting that Salicaceae was derived from ancestor family possesses elongate bilateral symmetry pollen. This postulation was supported by (7), where they demonstrated that the radiosymetry and isopolar characters are relatively advanced characters evolved from primitive types through intermediate stage. The second relatively advanced character is the elliptic pollen shape. This result was supported by (7), where they claimed that elliptic is a relatively 
advanced character derived from boat-shaped monosulcate pollen. The present investigation denoted both primitive and advanced characters are represented in the studied species, where $S$. mucronata has the smallest grain size and the coarseness exine reticulum. On the other hand, $S$. tetrasperma has the largest grain size and the coarsest exine reticulum. This result was confirmed by (26) where they claimed that large pollen grain size with coarse reticulate exine in Eucharis (Amaryllidaceae) is considered as a primitive character.

Wodehouse RP 1937(8) mentioned that in pollen grain of genus Salix, the mesh of the reticulum is generally coarse toward the centers of the lunes, finer toward the poles, and sharply bounded along the margins of the furrows.

Knowledge of genetic relationships among genotypes is useful in any plant breeding program. In Salix, there is currently limited information on genetic diversity and genetic relationships within and between species, clones and hybrids in the gene pool (27).

Within the limits of male and female genotypes available in this study, the RAPD bands OPP-01900, OPP-01870, OPA-07800, OPA-07650, OPA-07350, OPA-201300, OPA-201100, OPO141200, OPO-14700, OPO-14500, OPA-18300 and OPD-041300 appeared to be the female sex-related DNA marker in S. mucronata. On the other hand the RAPD bands OPA-071800,OPA-071350, OPA07600, OPO-14900, OPO-14800, OPO-14600, OPA-05830, OPA-05800, OPA-05620, OPA-18870 and OPD-04550 clearly distinct to be male sexrelated DNA marker in two studied Salix species. These results are supported by(28) who reported that the RAPD bands used were linked to a sex determing locus in family Salicaceae. On the other hand, the approach of RAPD-PCR technology has been successfully applied to identify the sex of $H$. rhamnoides (29); in addition, (30) used RAPD and SCAR analysis to differentiate between sexual forms of Papaya.

\section{Acknowledgment}

This research was funded by the Deanship of Scientific Research at Princess Nourah bint Abdulrahman University through the Fast-track Research Funding Program.

\section{Authors' declaration:}

- Conflicts of Interest: None.

- We hereby confirm that all the Figures and Tables in the manuscript are mine ours. Besides, the Figures and images, which are not mine ours, have been given the permission for republication attached with the manuscript.

- Ethical Clearance: The project was approved by the local ethical committee in University of Beni-Suef.

\section{References:}

1. Wu J, Nyman T, Wang D-C, Argus GW, Yang Y-P, Chen J-H. Phylogeny of Salix subgenus Salix s.l. (Salicaceae): delimitation, biogeography, and reticulate evolution. BMC Evol Biol [Internet]. 2015;15(1):31. Available from: https://doi.org/10.1186/s12862-015-0311-7

2. Angaji SA, Ghahremaninejad F, Mousavi SF, Tabrizi FM. Study of genetic variation in Salix using molecular markers. Adv Environ Biol. 2012;6(11):2982-5.

3. He L, CHEN S, Zhang Z-X. Taxonomy and nomenclature of Salix muliensis, S. wuxuhaiensis and S. floccosa. Phytotaxa. 2016;286(4):277-84.

4. Boulos L. Flora of Egypt: Geraniaceae-Boraginaceae. Vol. 2. Al Hadara Pub.; 1999.

5. Citak BY. A palynological survey of the genus Iberis (Brassicaceae), known as candytufts, in Turkey. Phytotaxa. 2019;397(3):213-24.

6. Mallick PK. Pollen Morphology of Angiosperms of Central Nepal. Int J Appl Sci Biotechnol. 2019;7(1):102-7.

7. Walker JW, Doyle JA. The bases of angiosperm phylogeny: palynology. Ann Missouri Bot Gard. 1975;664-723.

8. Wodehouse RP. Pollen grains: their structure, identification and significance in science and medicine. J Nerv Ment Dis. 1937;86(1):104.

9. Erdtman G. Pollen morphology and plant taxonomy Angiosperms Almqvist \& Wiksell. Slockholm Chron 80tanica Co Waltham M'ISS. USA 539p. 1952;

10. Williams JGK, Kubelik AR, Livak KJ, Rafalski JA, Tingey S V. DNA polymorphisms amplified by arbitrary primers are useful as genetic markers. Nucleic Acids Res. 1990;18(22):6531-5.

11. Sevġndġk E, Paksoy YM, Aydoğan M, Topseçer F. Genetic variation and molecular relationships taxa of Conringia heist. ex Fabr.(Brassicaceae) based on RAPD markers in Turkey. Genetika. 2020;52(1):10714.

12. Borsai O, Hârta M, Szabo K, Kelemen C-D, Andrecan FA, Codrea M-M, et al. Evaluation of genetic fidelity of in vitro-propagated blackberry plants using RAPD and SRAP molecular markers. Hortic Sci. 2020;47(1):21-7.

13. Mohammed IA, Mohamed IA. Validation of RAPD and ISSR Markers Used for Sex Determination in Date Palm Grown under Sudan Conditions. Adv Res Life Sci. 2019;3(1):17-22.

14. Ahmed SM, Fadl MA. Genetic relatedness among solanum L. species assayed by seed morphology and isozyme markers. Pakistan J Bot. 2016;48(5):2011-6.

15. Muschler R. A Manual Flora of Egypt. Vol 2. A Man Flora Egypt Vol 2. 1912;

16. Tackholm. Students' flora of Egypt. Cairo (Egypt) 
Cairo University; 1974.

17. Rasheed F, Yaqoob S, Ahmad HM. Forest Types of Pakistan

18. Porebski S, Bailey LG, Baum BR. Modification of a CTAB DNA extraction protocol for plants containing high polysaccharide and polyphenol components. Plant Mol Biol Report. 1997;15(1):8-15.

19.Wendel JF, Weeden NF. Visualization and interpretation of plant isozymes. In: Isozymes in plant biology. Springer; 1989. p. 5-45.

20.Kahlem G. Isolation and localization by histoimmunology of isoperoxidases specific for male flowers of the dioecious species Mercurialis annua $\mathrm{L}$. Dev Biol. 1976;50(1):58-67.

21.Qacif N, Baaziz M, Bendiab K. Biochemical investigations on peroxidase contents of male and female inflorescences of date palm (Phoenix dactylifera L.). Sci Hortic (Amsterdam). 2007;114(4):298-301.

22.Satil F, Kaya A, Ünal M. Fruit, seed and pollen morphology of Chorispora DC. species (Brassicaceae) of Turkey. Bangladesh $\mathrm{J}$ Bot. 2018;47(3):459-66.

23.Maw KH. Pollen morphological studies on five species of the family Nyctaginaceae in Amarapura Township. 2019;(1):1-10.

24.Salim MA, Mohamed A-SH, Tantawy ME.
Morphological study of some taxa of Ranunculaceae Juss in Egypt (anatomy and pollen grains). Beni-Suef Univ J Basic Appl Sci. 2016;5(4):310-9.

25. Hutchinson J. Evolution and phylogeny of flowering plants: dicotyledons, facts and theory. 1969.

26. Meerow AW, Dehgan B. Pollen morphology of the Eucharideae (Amaryllidaceae). Am J Bot. 1988;75(12):1857-70.

27. Raja R, Singh NB, Bhat SS. Assessment of genetic diversity among high yielding selected Salix clones, using RAPD and SSR markers. Genetika. 2018;50(3):983-94.

28.Gotoveckienè E, Verbylaitè R, Kuusienè S. Identification of Gender in Full-Sibling Progeny of Hybrid Aspen Using RAPD Markers Linked to Putative Sex Determination Locus in Salicacea Family Plants. Smart Bio. 2017;88.

29. Zhou W, Wang Y, Zhang G, Luan G, Chen S, Meng $\mathrm{J}$, et al. Molecular Sex Identification in Dioecious Hippophae rhamnoides L. via RAPD and SCAR Markers. Molecules. 2018;23(5):1048.

30. Modi A, Suthar K, Thakkar P, Mankad MC, Kumari S, Narayanan S, et al. Evaluation of sex specific RAPD and SCAR markers linked to papaya (Carica papaya L.). Biocatal Agric Biotechnol. 2018;16:2716.

\section{دراسة مقارنه بين الأنواع التي تتبع جنس الصفصاف في مصر ولاء حسن1 \\ 1قسم الاحباء، كلية العلوم، جامعة الاميرة نورة بنت عبدالرحمن، الرياض، المملكة العربية السعودية ،قسم النبات و الميكروبيولوجي، كلية

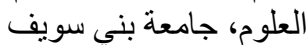

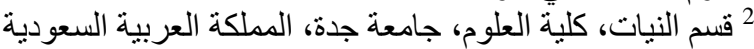

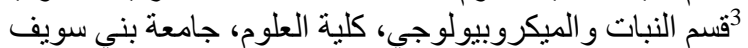 4 قسم العلوم الحيوية، جامعة الملك عبد العزيز المملكة العربية السعودية رقسم النبات و الميكروبيولوجي، كلية العلوم، جامعة بني سويف}

جنس الصفصاف هو من العائلة الصفصافية منتشر في نصف الكرة الثمالي علي مستوي العالم. ممثل في مصر بنوعان

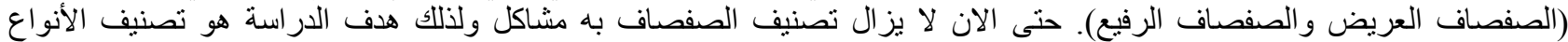

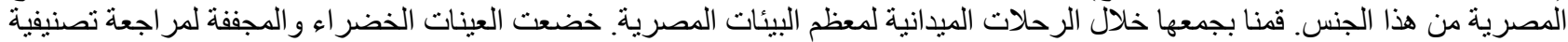

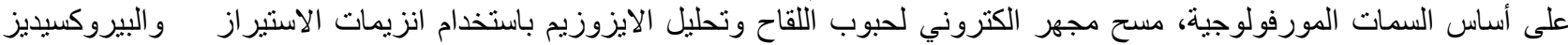

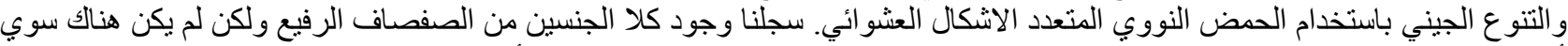

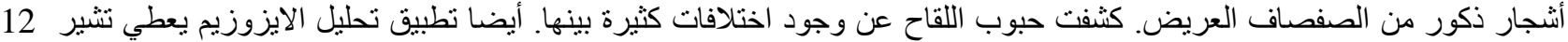

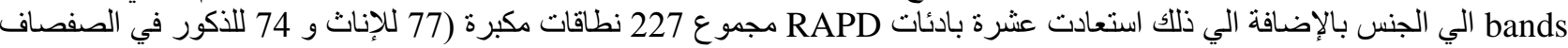
الرفيع و 76 للذكور في الصفصناف العريض).

الكلمات المفتاحية: مصر، إيزوزيم، حبوب اللقاح، Salix ،RAPD 